\title{
The Glucagon-Like Peptide-1 Receptor Agonist Liraglutide Improves Hypoxia-Induced Pulmonary Hypertension in Mice Partly via Normalization of Reduced ET $_{B}$ Receptor Expression
}

\author{
J. HONDA ${ }^{1}$, T. KIMURA ${ }^{1}$, S. SAKAI ${ }^{1}$, H. MARUYAMA ${ }^{1}$, K. TAJIRI ${ }^{1}$, N. MURAKOSHI ${ }^{1}$, \\ S. HOMMA ${ }^{1}$, T. MIYAUCHI ${ }^{1}$, K. AONUMA ${ }^{1}$ \\ ${ }^{1}$ Department of Cardiology, Faculty of Medicine, University of Tsukuba, Tsukuba, Japan
}

Received November 30, 2017

Accepted March 2, 2018

\begin{abstract}
Summary
The glucagon-like peptide-1 receptor (GLP-1R) agonist liraglutide is an incretin hormone mimetic used in the treatment of diabetes. However, the effects of liraglutide on pulmonary hypertension $\mathrm{PH}$ ) and pulmonary endothelin (ET) system are unknown. Eight-week-old C57BL6/J mice were injected liraglutide or vehicle for 5 weeks. One week after injection, the mice were exposed to either room air (normoxia) or chronic hypoxia $\left(\begin{array}{lll}10 & \% & O_{2}\end{array}\right)$ for 4 weeks. The right ventricular systolic pressure (RVSP) was significantly higher in hypoxia + vehicle group than in normoxia + vehicle group. ET-1 mRNA expression in the lungs was comparable among all the groups. $\mathrm{ET}_{\mathrm{B}} \mathrm{mRNA}$ and protein expression in the lungs was significantly lower in hypoxia + vehicle group than in normoxia + vehicle group. The above changes were normalized by liraglutide treatment. The expression of phospho-eNOS and phospho-AMPK proteins in the lungs was significantly higher in hypoxia + liraglutide group than in normoxia + vehicle group. We demonstrated for the first time that liraglutide effectively improved RVSP and RV hypertrophy in hypoxia-induced $\mathrm{PH}$ mice by activating eNOS through normalization of impaired $\mathrm{ET}_{\mathrm{B}}$ pathway and augmentation of AMPK pathway. Therefore, GLP-1R agonists can be promising therapeutic agents for $\mathrm{PH}$.
\end{abstract}

\section{Key words}

GLP-1R • Pulmonary hypertension - Liraglutide - $\mathrm{ET}_{\mathrm{B}}$ receptor • eNOS

\section{Corresponding author}

T. Kimura, Department of Cardiology, Faculty of Medicine, University of Tsukuba, 1-1-1 Tennoudai, Tsukuba, Ibaraki 305-8575, Japan. Fax: +81-29-853-3143. E-mail: kimurat@md.tsukuba.ac.jp

\section{Introduction}

Pulmonary hypertension (PH) is a disease affecting small pulmonary arteries and is characterized by vascular proliferation and remodeling. It results in a progressive increase in pulmonary vascular resistance and mean pulmonary arterial pressure more than $25 \mathrm{~mm} \mathrm{Hg}$ (Barst et al. 2004), and ultimately results in right ventricular (RV) failure and death. Various endogenous components are considered to be involved in the worsening of PH. Endothelin-1 (ET-1), an endothelium-derived potent vasoconstrictor peptide with vasoproliferative activity (Yanagisawa et al. 1988, Miyauchi and Goto 2013, Gohar et al. 2016, Barton and Sorokin 2016), is considered to play an important role in the progression of PH (Miyauchi et al. 1993, Miyauchi and Goto 2013, Clozel 2016, Davenport et al. 2016). The effects of ET-1 are mediated via the G-protein-coupled receptors, endothelin receptor type $\mathrm{A}\left(\mathrm{ET}_{\mathrm{A}}\right)$ and endothelin receptor type $\mathrm{B}\left(\mathrm{ET}_{\mathrm{B}}\right)$ (Miyauchi and Goto 2013, Gohar et al. 2016, Barton and Sorokin 2016, Davenport et al. 2016). $\mathrm{ET}_{\mathrm{A}}$ stimulation has been considered to induce harmful responses such as vasoconstriction and vasoproliferation. In various situations, the stimulation of $\mathrm{ET}_{\mathrm{B}}$ was considered to induce beneficial responses, such as nitric oxide (NO) release from the endothelium (Barton and Yanagisawa 2008, Thorin et al. 2010, Rodriguez-Pascual et al. 2011, Miyauchi and Goto 2013, Davenport et al. 2016). Endothelin receptor antagonists (ERA) are currently in clinical use for the treatment of patients with $\mathrm{PH}$ (Miyauchi and Goto 2013, Clozel 2016, Davenport et al. 
2016). In addition, prostacyclin derivatives and phosphodiesterase type 5 inhibitors (PDE5 inhibitors) are currently in clinical use (Clozel 2016). Nevertheless, PH is a devastating disease with high mortality. Therefore, development of other drugs is expected to improve the survival of patients with $\mathrm{PH}$.

The glucagon-like peptide-1 receptor (GLP-1R) agonist liraglutide is an incretin hormone mimetic that is used in the treatment of diabetes mellitus. GLP-1 is secreted in a nutrient-dependent manner. It stimulates insulin secretion and inhibits both glucagon secretion and gastric emptying, thereby reducing postprandial hyperglycemia (Drucker et al. 2006, Irwin et al. 2001). GLP-1 has been shown to exhibit favorable cardiovascular effects in preclinical and clinical studies. It has been reported that GLP-1 exhibits cardioprotective and vasodilatory effects in mice (Ban et al. 2008). Recently, GLP-1R agonists were reported to inhibit endothelial dysfunction (Gaspari et al. 2013), inflammation (Liu et al. 2009, Arakawa et al. 2010), and cell proliferation (Goto et al. 2011). On the assumption that the aforementioned favorable effects of GLP-1R agonists occur in the pulmonary arteries, it seems likely that GLP-1R agonists would be effective in ameliorating PH. However, the effect of GLP-1R agonists on PH has not been reported to date. Therefore, in this study, we aimed to examine the effects of GLP-1R agonist on PH in a mouse model of hypoxia-induced $\mathrm{PH}$. In addition, we investigated the effects of GLP-1R agonists on the lung ET systems $\left(\mathrm{ET}-1, \mathrm{ET}_{\mathrm{A}}\right.$, and $\left.\mathrm{ET}_{\mathrm{B}}\right)$.

\section{Methods}

\section{PH mouse model and experimental design}

Wild-type male C57BL/6J mice (8-week-old) were purchased from CLEA Japan, Inc. (Tokyo, Japan). The mice were injected liraglutide $(200 \mu \mathrm{g} / \mathrm{kg} / \mathrm{day})$ or saline intraperitoneally. This concentration of liraglutide was selected to be effective in mice experiments as previously reported (Gaspari et al. 2013, Shirakawa et al. 2012, Noyan-Ashraf et al. 2013). One week after injection, the mice were exposed to room air (normoxia) or chronic hypoxia $\left(10 \% \mathrm{O}_{2}\right)$ for 4 weeks. All animal experiments were approved by the Institutional Animal Experiment Committee of the University of Tsukuba and conform to the NIH guidelines for the care and use of laboratory animals. We divided the mice into the following four groups: normoxia + vehicle (saline administration) group $(n=6)$; normoxia + liraglutide group $(n=6)$; hypoxia + vehicle group $(n=6)$; and hypoxia + liraglutide group $(\mathrm{n}=6)$.

\section{Hemodynamic measurement}

Blood pressure and heart rate were assessed non-invasively using a Volume Pressure Recording system (Kent Scientific Corporation, Torrington, USA). The mice were accustomed to the tail cuff device for 20 min before measurements.

To assess RV systolic pressure (RVSP), the mice were anesthetized with sodium pentobarbital $(50 \mathrm{mg} / \mathrm{kg}$ intraperitoneally). The RV apex was exposed via a subdiaphragmatic incision. An apical stab was made with a 27-gauge needle containing a fiber pressure sensor (FPI-LS-PT9; FISO Technologies, Inc., Quebec, Canada). RVSP measurements were obtained at a steady state. All signals were analyzed with a signal conditioner (FPI-LS-10; FISO Technologies, Inc.) and data acquisition system (LabTrax 4, World Precision Instruments, Sarasota, FL, USA), and then analyzed using a software (LabScribe2, iWorx Systems, Inc., Dover, NH, USA).

RNA extraction and quantitative real-time reversetranscription polymerase chain reaction ( $q R T-P C R$ )

All lung tissues were frozen and stored at $-80^{\circ} \mathrm{C}$. For preparation of total RNA, the lung tissue was homogenized using a bead kit (MagNA Lyser Green Beads; Roche Life Science, Indianapolis, IN, USA) according to the manufacturer's instructions. Total RNA samples from the lung tissue and cultured cells were prepared using an RNeasy Fibrous Tissue Mini Kit (Qiagen, Venlo, Netherlands), and $1 \mu \mathrm{g}$ of total RNA was reverse transcribed to complementary DNA by using a High-Capacity cDNA Reverse Transcription Kit (Thermo Fisher Scientific, Inc., Waltham, MA, USA). The mRNA expression levels of the target genes were analyzed by the LightCycler 96 system (Roche Applied Science, Penzberg, Germany) with a Universal Probe Library (Roche Applied Science). Glyceraldehyde 3-phosphate dehydrogenase (GAPDH) RNA was used as an internal control (\#05 046211 011; Roche Diagnostics $\mathrm{GmbH}$, Mannheim, Germany). PCR amplification was performed in duplicate as follows: 1 cycle at $95^{\circ} \mathrm{C}$ for $10 \mathrm{~min}$ and 40 cycles at $94^{\circ} \mathrm{C}$ for $15 \mathrm{~s}$ and $60^{\circ} \mathrm{C}$ for $1 \mathrm{~min}$. The following primers for mouse were used in the study: ET-1: 5'-TCTCTGCTGTTTGTGGCTTG-3' (sense), 5'-GAGCTCAGCGCCTAAGACTG-3' (antisense), ET receptor: 5'-TGTGAGCAAGAAATTCAAAAATTG-3' 
(sense), 5'-ATGAGGCTTTTGGACTGGTG-3' (antisense), $\mathrm{ET}_{\mathrm{B}}$ receptor: 5'-TCAGAAAACAGCCTTCATGC-3' (sense), 5'-GCGGCAAGCAGAAGTAGAA-3' (antisense), eNOS (endothelial nitric oxide synthase): 5'-ATCCAGTGCCCTGCTTCA-3' (sense), 5'-GCAGGG CAAGTTAGGATCAG-3' (antisense).

\section{Histological analysis of lung tissues}

First for the morphological analysis of the lungs, the hearts and lungs were flushed with saline and then dissected (Zhang et al. 2017). After that, the lungs were fixed with $4 \%$ paraformaldehyde, embedded in paraffin, sectioned into 3- $\mu \mathrm{m}$ thick slices, and stained with Elastica van Gieson. Images were obtained using a digital microscope (Biozero BZ-X700; Keyence, Osaka, Japan). Pulmonary vascular remodeling was quantified by assessing the medial wall thickness. To determine the degree of medial wall thickness, 10 muscular arteries categorized $<50 \mu \mathrm{m}$ and $\geq 50 \mu \mathrm{m}$ in diameter from each lung $(n=6)$ were randomly outlined by an observer blinded to the mouse genotype or pharmacological treatment. The degree of medial wall thickness expressed as the ratio of medial area to cross sectional area (Medial/CSA) was analyzed using the ImageJ software (Ver. 1.48, NIH, USA).

\section{Western blotting}

The lung tissues were homogenized with RIPA buffer on ice using MagNA Lyser Green Beads. The homogenate was centrifuged at 13,000 rpm for $30 \mathrm{~min}$ at $4{ }^{\circ} \mathrm{C}$. The concentrations of proteins extracted from lung homogenates were determined using the Pierce BCA Protein Assay Kit (Pierce, Rockford, IL, USA). The samples were separated by sodium dodecyl sulfatepolyacrylamide gel electrophoresis in 10-20\% polyacrylamide gradient gels and transferred onto a polyvinylidene difluoride membrane. The membrane was blocked with $3 \%$ skim milk in tris-buffered saline (TBS) containing $0.1 \%$ Tween 20 (TBST), incubated with primary antibodies $(1: 1,000)$ in a solution $(\mathrm{W} 00 \mathrm{H}$, DRC Co., Tokyo, Japan) overnight at $4{ }^{\circ} \mathrm{C}$, and then reacted with a horseradish peroxidase-conjugated goat anti-rabbit antibody (\#7074, Cell Signaling Technology, Boston, MA, USA) or rabbit anti-mouse antibody (\#7076, Cell Signaling Technology) at 1:10,000 in a solution (W00B, DRC) at $25^{\circ} \mathrm{C}$ for $60 \mathrm{~min}$. The following primary antibodies were used: eNOS (49G3) (\#9586, Cell Signaling Technology), Phospho-eNOS (Ser 1177) (\#9571, Cell Signaling Technology), AMPK (23A3)
(\#2603, Cell Signaling Technology), Phospho-AMPK (Thr 172) (\#2535, Cell Signaling Technology), $\mathrm{ET}_{\mathrm{A}}$ (\#AER-001, Alomone Labs, Jerusalem, Israel), $\mathrm{ET}_{\mathrm{B}}$ (\#AER-002, Alomone Labs), and GAPDH (MAB374, Merck Millipore, Billerica, MA, USA). The blots were visualized with a chemiluminescent reagent (ImmunoStar, Wako, Osaka, Japan) and CCD camera system (Light-Capture II, Atto Co., Tokyo, Japan) and analyzed with a software (CS Analyzer ver. 3.0, Atto Co.) as described previously (Sakai et al. 2016).

\section{Statistics}

All data are expressed as mean \pm SEM. The experimental groups were compared by one-way analysis of variance followed by Tukey's test for multiple comparisons. Differences were considered statistically significant at $\mathrm{p}<0.05$. The analysis was performed using IBM SPSS version 22.0 software (IBM Co., Armonk, NY, USA).

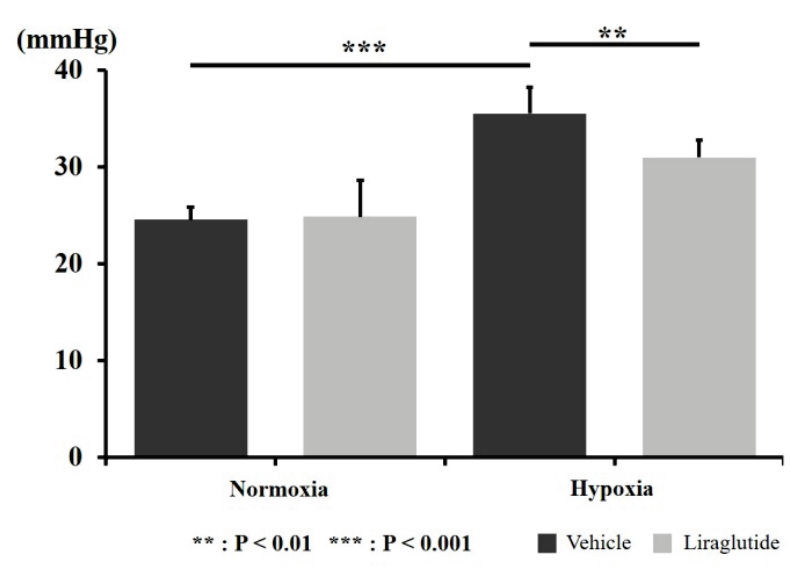

Fig. 1. Right ventricular systolic pressure ( $n=6$ for each group). The bar graphs show the mean \pm SEM of the groups. $* * p<0.01$, $* * * p<0.001$.

\section{Results}

Effects of liraglutide on body weight, systemic blood pressure, heart rate, right ventricle, left ventricle, RVSP, and glucose level

We investigated whether liraglutide administration attenuated hypoxia-induced $\mathrm{PH}$ in mice. After 4 weeks of exposure to chronic hypoxia $\left(10 \% \mathrm{O}_{2}\right)$, a significant increase in both RVSP and the ratio of weight of the $R V$ wall to body weight (RV/BW) was observed in hypoxia + vehicle group compared with the normoxia + vehicle group (Fig. 1, Table 1). Notably, hypoxia + liraglutide group showed 
a significant reduction in RVSP $(34.2 \pm 2.2 \mathrm{~mm} \mathrm{Hg}$ vs. $30.0 \pm 1.5 \mathrm{~mm} \mathrm{Hg}, \mathrm{p}<0.01, \mathrm{n}=6$ ) and RV/BW compared with the hypoxia + vehicle group. In contrast, there were no significant differences in systolic blood pressure and ratio of weight of the left ventricular plus interventricular septum to BW among all groups. The reduction in lung weight was less than $5 \%$, the reduction in right ventricular systolic pressure was $13 \%$ and the reduction in right ventricular weight was $16 \%$ by liraglutide administration under hypoxia. Lung weight, heart rate, and blood sugar level were significantly reduced in the hypoxia groups compared with those in the normoxia groups (Table 1).

Table 1. Heart rate, lung weight, body weight, hemodynamic states, and blood sugar level in each group.

\begin{tabular}{lcccc}
\hline & \multicolumn{2}{c}{ Normoxia } & \multicolumn{2}{c}{ Hypoxia } \\
\cline { 2 - 5 } & Vehicle & Liraglutide & Vehicle & Liraglutide \\
\hline$B W(g)$ & $26.5 \pm 0.3$ & $25.7 \pm 0.2$ & $26.7 \pm 0.7$ & $25.3 \pm 0.6$ \\
$S B P(\mathrm{~mm} \mathrm{Hg})$ & $107.5 \pm 3.0$ & $107.7 \pm 4.1$ & $108.4 \pm 4.4$ & $109.6 \pm 3.2$ \\
$H R(\mathrm{bpm})$ & $678 \pm 16$ & $648 \pm 17$ & $565 \pm 40^{*}$ & $595 \pm 28$ \\
$R V(\mathrm{mg}) / B W(g)$ & $0.68 \pm 0.03$ & $0.77 \pm 0.10$ & $0.98 \pm 0.06^{*}$ & $0.82 \pm 0.12^{*} \S$ \\
$L V+I V S(m g) / B W(g)$ & $3.12 \pm 0.05$ & $3.23 \pm 0.03^{*}$ & $3.23 \pm 0.10$ & $2.93 \pm 0.12$ \\
$\operatorname{Lung}(\mathrm{mg}) / B W(g)$ & $4.55 \pm 0.12$ & $4.87 \pm 0.14^{*}$ & $6.58 \pm 0.15^{*}$ & $6.28 \pm 0.11^{*}$ \\
$B S(\mathrm{mg} / \mathrm{dl})$ & $277 \pm 11.5$ & $257 \pm 13.6^{*}$ & $143 \pm 15.8^{*}+$ & $133 \pm 9.5^{*}+$ \\
\hline
\end{tabular}

Results are presented as mean \pm SEM ( $n=6$ for each group). BW, body weight; SBP, systolic blood pressure; HR, heart rate; RV, right ventricle; LV, left ventricle; IVS, interventricular septum; BS, blood sugar. ${ }^{*} p<0.05$ vs. normoxia + vehicle; $\dagger p<0.05$ vs. normoxia + liraglutide; $\S p<0.05$ vs. hypoxia + vehicle.

(e) Medial wall thickness

(a) Normoxia + Vehicle

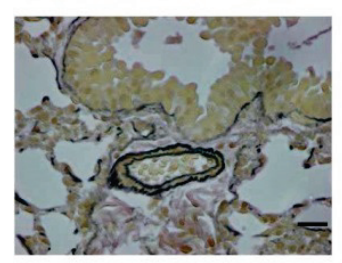

(c) Hypoxia + Vehicle

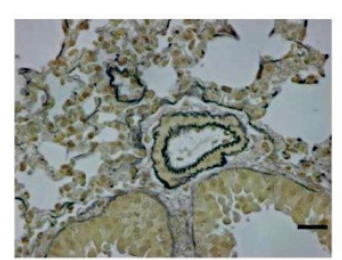

(b) Normoxia + Liraglutide

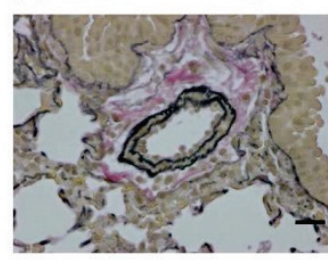

(d) Hypoxia + Liraglutide
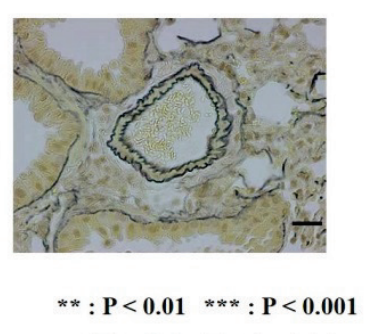

Vehicle Liraglutide

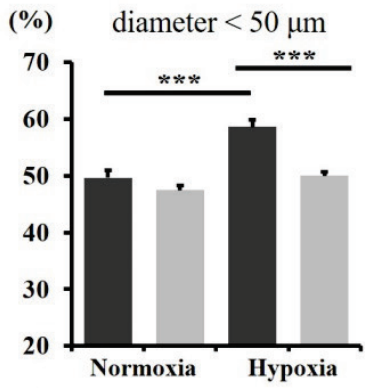

(\%)

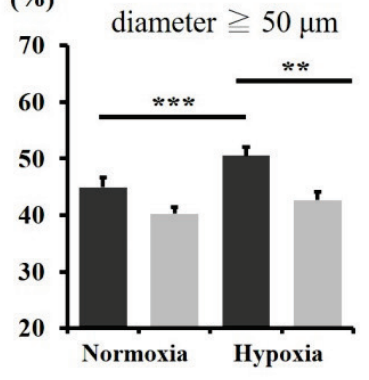

Fig. 2. Representative images of pulmonary artery in (a) normoxia + vehicle, (b) normoxia + liraglutide, (c) hypoxia + vehicle, and (d) hypoxia + liraglutide groups. The pulmonary arteries were stained with Elastica van Gieson (scale bar: $10 \mu \mathrm{m}$ ). (e) These graphs show the ratio of medial area to cross sectional area of pulmonary arteries smaller than $50 \mu \mathrm{m}$ (upper panel) and larger than $50 \mu \mathrm{m}$ (lower panel) in diameter. Ten muscular arteries categorized $<50 \mu \mathrm{m}$ and $\geq 50 \mu \mathrm{m}$ in diameter from each lung $(n=6)$ were randomly outlined by an observer blinded to the mouse genotype or pharmacological treatment. The error bars represent the mean \pm SEM. ${ }^{* *} p<0.01, * * * p<0.001$.
Effects of liraglutide on pulmonary medial wall thickening

To determine the degree of medial wall thickening in pulmonary arteries, Elastica van Gieson staining was performed. The representative images of lung tissues are shown in Figures 2a-2d. The medial wall thickness of arteries categorized $<50 \mu \mathrm{m}$ and $\geq 50 \mu \mathrm{m}$ in diameter increased significantly in the hypoxia + vehicle group compared with that in the normoxia + vehicle group. However, medial wall thickening in the hypoxia + liraglutide group decreased significantly compared with that in the hypoxia + vehicle group (Fig. 2e). These 
results suggested that medial wall thickening was reduced by liraglutide treatment.

Effect of liraglutide on mRNA expression of eNOS and ET systems

To investigate the effect of liraglutide on the expression of eNOS and ET systems, we determined mRNA expression levels in the lung tissue by using real-time PCR. The mRNA expression level of eNOS in hypoxia + liraglutide group was significantly higher than that in hypoxia + vehicle group (Fig. 3a). Next, we investigated the mRNA expression of ET systems. No significant difference in the mRNA expression level of ET-1 was observed among the groups (Fig. 3b). However, liraglutide normalized the reduced expression of $\mathrm{ET}_{\mathrm{A}}$ and $\mathrm{ET}_{\mathrm{B}}$ induced by chronic hypoxia (Figs $3 \mathrm{c}$ and $3 \mathrm{~d}$ ). (a)

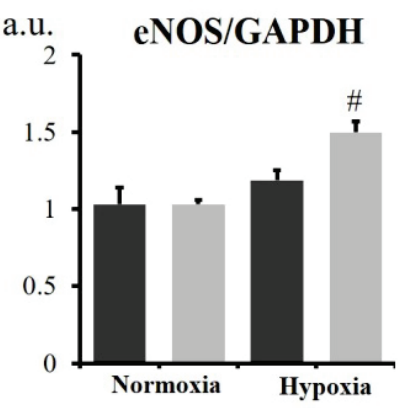

(c) a.u.

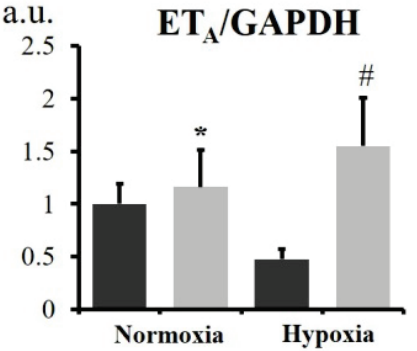

(b)

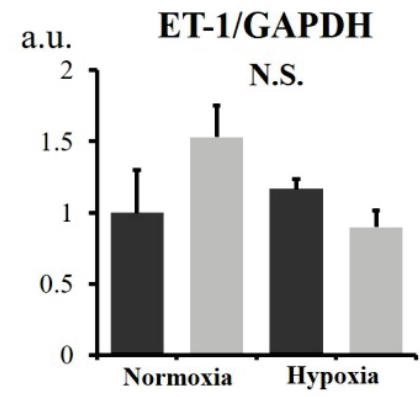

(d) a.u.

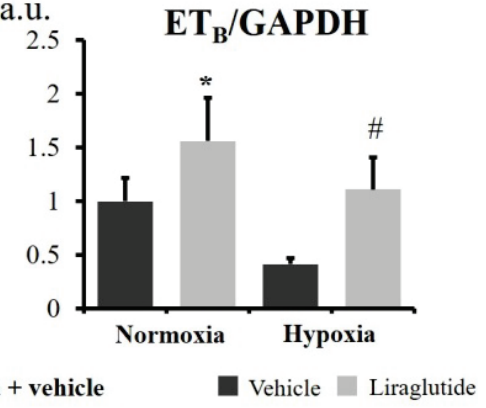

Fig. 3. Gene expression levels in the lung tissues analyzed by real-time PCR ( $n=6$ for each group). (a) The mRNA expression level of endothelial nitric oxide synthase (eNOS) and (b) endothelin-1 (ET-1) in all groups. (c) Endothelin receptor type $A\left(E T_{A}\right)$ and (d) Endothelin receptor type B $\left(\mathrm{ET}_{\mathrm{B}}\right)$. The error bars represent the mean \pm SEM. ${ }^{*} p<0.05$, vs. normoxia + vehicle, $\# p<0.05$ vs. hypoxia + vehicle.
Effects of liraglutide on the protein expression of eNOS, phospho-eNOS, AMPK, phospho-AMPK, ET $T_{A}$, and $E T_{B}$ in the lungs

We determined the expression of different proteins by Western blot analysis in the lung tissues. In Figure 4a, representative expressions of eNOS, phosphoeNOS, AMPK, phospho-AMPK are shown. The expression of eNOS and AMPK was comparable among all the groups. However, the expression of phospho-eNOS and phospho-AMPK in hypoxia + liraglutide group increased compared with that in hypoxia + vehicle group (Fig. 4a).

We further examined the Western blot analysis for $\mathrm{ET}_{\mathrm{A}}$ and $\mathrm{ET}_{\mathrm{B}}$. The representative expressions and the statistical analysis of these data are shown in Figures 4b, 4c and 4d. Hypoxia significantly increased the expression of $\mathrm{ET}_{\mathrm{A}}$ and liraglutide administration under hypoxia further increased the expression of $\mathrm{ET}_{\mathrm{A}}$ (Figs $4 \mathrm{~b}$ and $4 \mathrm{c}$ ). Nevertheless, hypoxia did not change the expression of $\mathrm{ET}_{\mathrm{B}}$ whereas liraglutide administration under hypoxia significantly increased the expression of $\mathrm{ET}_{\mathrm{B}}$ (Figs $4 \mathrm{~b}$ and $4 \mathrm{~d}$ ).

\section{Discussion}

In the present study, we demonstrated that the GLP-1R agonist liraglutide significantly reduced RVSP in hypoxia-induced PH mice model. This study also demonstrated that chronic administration of liraglutide inhibited the medial thickening of pulmonary arteries and development of RV hypertrophy in hypoxia-induced $\mathrm{PH}$ mice. For the first time, we demonstrated that a GLP-1R agonist effectively normalized the reduction in $\mathrm{ET}_{\mathrm{B}}$ expression in the lungs of mice. In addition, we demonstrated for the first time that the GLP-1R agonist liraglutide augmented the expression of phospho-eNOS protein in lung tissues of $\mathrm{PH}$ mice. Thus, we suggest that GLP-1R agonists are effective in ameliorating PH, and this beneficial effect is partly attributed to the normalization of reduction in $\mathrm{ET}_{\mathrm{B}}$-mediated eNOS activation in the pulmonary artery. The findings of this study can offer insights into a novel strategy for the treatment of PH using a GLP-1R agonist. 
(a)

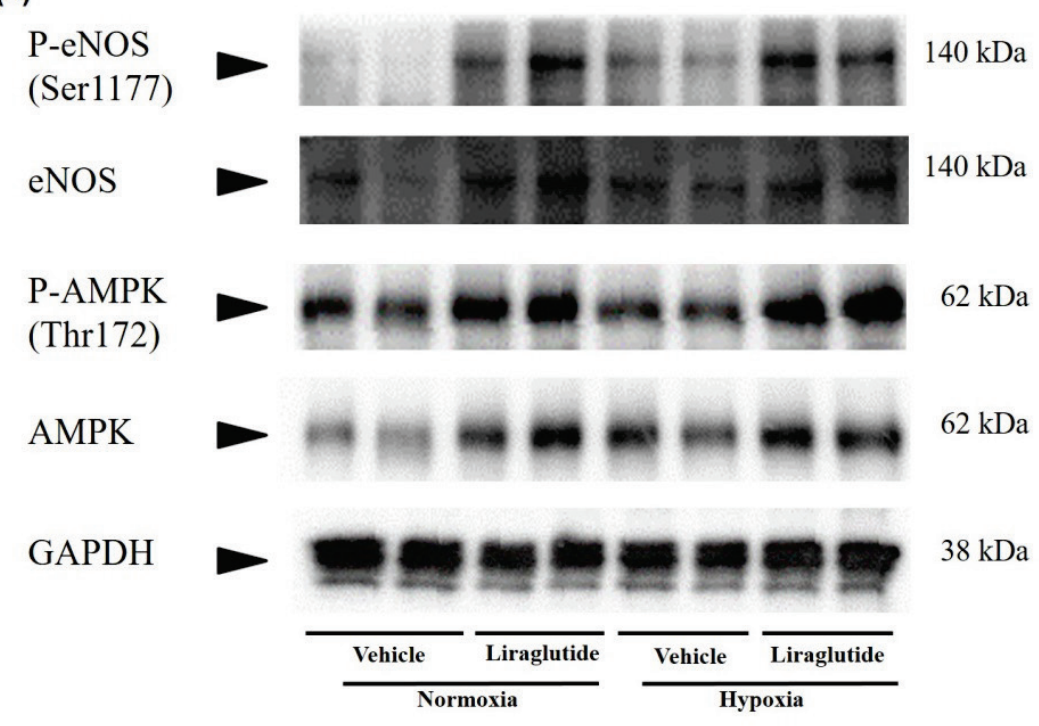

(b)

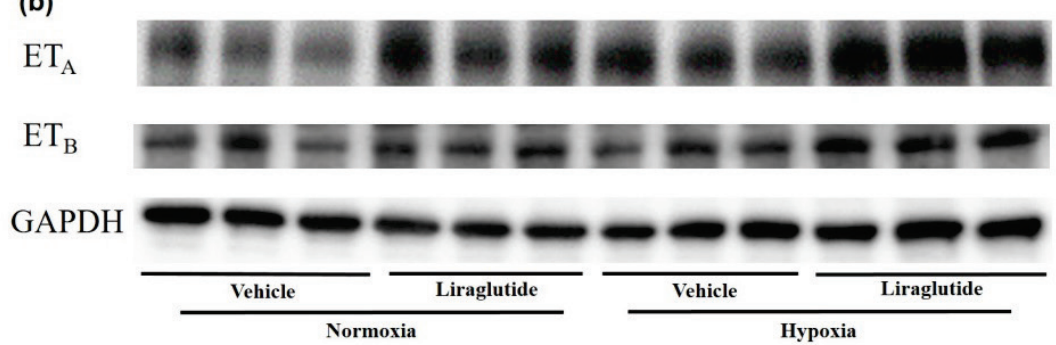

(c) a.u.

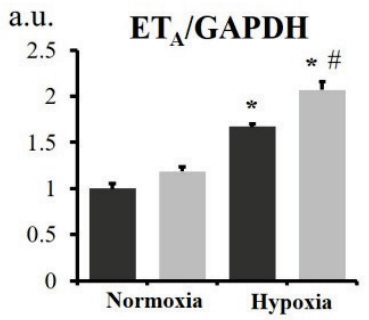

*: $\mathrm{P}<0.05$ vs normoxia + vehicle, \# : $\mathrm{P}<0.05$ vs hypoxia + vehicle

eNOS is an enzyme that catalyzes the production of NO, which plays an important role in vasorelaxation and maintaining vascular homeostasis. Notably, eNOS and NO expression levels were found to be reduced in PH patients (Giaid et al. 1995, Seimetz et al. 2011). In addition, a previous study has shown that liraglutide augmented the expression of eNOS in cultured vascular endothelial cells (Dai et al. 2013). Therefore, the inhibition of PH development would be partly obtained by the eNOS enhancement by liraglutide administration in the lungs of PH mice. We considered that the eNOS activation was mediated by two pathways: normalization of impaired $\mathrm{ET}_{\mathrm{B}}$-mediated signaling pathway and augmentation of AMPK signaling pathway (Fig. 5).

In the ET signaling pathway, ET-1 is a vasoconstrictor and proinflammatory peptide produced by vascular endothelial cells (Yanagisawa et al. 1988,
Fig. 4. Effects of liraglutide on the protein expression of eNOS, P-eNOS, AMPK, P-AMPK, $\mathrm{ET}_{\mathrm{A}}$, and $\mathrm{ET}_{\mathrm{B}}$ receptors. (a) Representative Western blots of eNOS, P-eNOS, AMPK, P-AMPK and GAPDH in the lungs $(n=2)$. (b) Representative Western blots of $\mathrm{ET}_{\mathrm{A}}$ receptor, $\mathrm{ET}_{\mathrm{B}}$ receptor, and $\mathrm{GAPDH}$ in the lungs $(n=3)$. (c, d) Bar graphs show relative expressions of $\mathrm{ET}_{\mathrm{A}}(\mathbf{c})$ and $\mathrm{ET}_{\mathrm{B}}$ (d) to GAPDH (an internal control) analyzed by densitometry software. Values are expressed as the mean \pm SEM $(n=3) .{ }^{*} p<0.05$ vs. normoxia + vehicle, $\# p<0.05$ vs. hypoxia + vehicle. AMPK, adenosine monophosphate-activated protein kinase; eNOS, endothelial nitric oxide synthase; $E T_{A}$, endothelin receptor type $A ; E T_{B}$, endothelin receptor type $B$; GAPDH, glyceraldehyde 3-phosphate dehydrogenase; P-AMPK, phospho-AMPK; P-eNOS, phospho-eNOS. 
$\mathrm{ET}_{\mathrm{B}}$ was considered to induce beneficial responses, such as increase in the production of NO and prostacyclin $\left(\mathrm{PGI}_{2}\right)$ by endothelial cells to cause vasodilatation. $\mathrm{ET}_{\mathrm{B}}$ functions as a "clearance receptor" to prevent excessive $\mathrm{ET}_{\mathrm{A}}$ stimulation by endogenous ET-1 (Thorin et al. 2010, Miyauchi and Goto 2013, Davenport et al. 2016). $E_{\mathrm{A}}$ is highly expressed in vascular smooth muscle cells, but not in endothelial cells (Hosoda et al. 1991, Miyauchi and Goto 2013, Davenport et al. 2016). Stimulation of $\mathrm{ET}_{\mathrm{A}}$ by ET-1 induces contraction and proliferation of vascular smooth muscle cells, which contributes to the development of PH (Frumkin et al. 2012, Rubin et al. 2012, Miyauchi and Goto 2013, Davenport et al. 2016). $\mathrm{ET}_{\mathrm{B}}$ is highly expressed in endothelial cells (Ogawa et al. 1991, Miyauchi and Goto 2013, Davenport et al. 2016), where $\mathrm{ET}_{\mathrm{B}}$ activation by ET-1 accelerates the production of vasodilators, such as $\mathrm{NO}$ and $\mathrm{PGI}_{2}$, and the clearance of ET-1 from the circulation (Warner et al. 1989, de Nucci et al. 1988, Fukuroda et al. 1994, Dupuis et al. 1996, Miyauchi and Goto 2013). The endothelial NO generation mediated via the $\mathrm{ET}_{\mathrm{B}}$ inhibits proliferation of vascular smooth muscle cells (Garg et al. 1989, Miyauchi and Goto 2013, Davenport et al. 2016). In some patients with $\mathrm{PH}$, vascular $\mathrm{ET}_{\mathrm{A}}, \mathrm{ET}_{\mathrm{B}}$, and eNOS expression was reduced (Hall et al. 2011). However, in $\mathrm{PH}$ patients treated with bosentan and/or epoprostenol, $\mathrm{ET}_{\mathrm{A}}$ and $\mathrm{ET}_{\mathrm{B}}$ expression was normalized, whereas eNOS expression was increased (Hall et al. 2011). Other researchers have shown that the expression of $\mathrm{ET}_{\mathrm{A}}$ increased but $\mathrm{ET}_{\mathrm{B}}$ decreased under hypoxia (Wang et al. 2013, Wang et al. 2017, Gao et al. 2013). Therefore, the expressions of $\mathrm{ET}_{\mathrm{A}}$ and $\mathrm{ET}_{\mathrm{B}}$ under hypoxic conditions are controversial and depend on the experimental methods. In the present study, we revealed that liraglutide increased the expression of $\mathrm{ET}_{\mathrm{B}}$ and $\mathrm{ET}_{\mathrm{A}}$ in the lungs in a mouse model of $\mathrm{PH}$. The increase in $\mathrm{ET}_{\mathrm{A}}$ expression may affect vascular remodeling in $\mathrm{PH}$. Nevertheless, it is unclear whether the increase in $\mathrm{ET}_{\mathrm{A}}$ expression by liraglutide is beneficial or harmful for the setting of $\mathrm{PH}$. In addition, it has been reported that $\mathrm{ET}_{\mathrm{A}}$ was not present in endothelial cells (Hosoda et al. 1991). Therefore, we believe that the beneficial effect of liraglutide in the mouse model of hypoxia-induced $\mathrm{PH}$ was at least partly due to eNOS activation mediated by the normalization of impaired $\mathrm{ET}_{\mathrm{B}}$ signaling (Fig. 5). The number of patients with $\mathrm{PH}$ treated with a drug combination (e.g. ambrisentan/tadalafil) is increasing. Ambrisentan is a selective $\mathrm{ET}_{\mathrm{A}}$ blocker. Liraglutide could

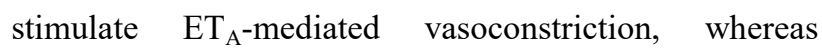
simultaneously liraglutide could enhance $\mathrm{ET}_{\mathrm{B}}$-mediated vasodilatation by increasing cGMP. It is of great interest that liraglutide could be tested in combination with an $\mathrm{ET}_{\mathrm{A}}$ blocker because the increase in $\mathrm{ET}_{\mathrm{A}}$ by liraglutide could be antagonized in this setting.

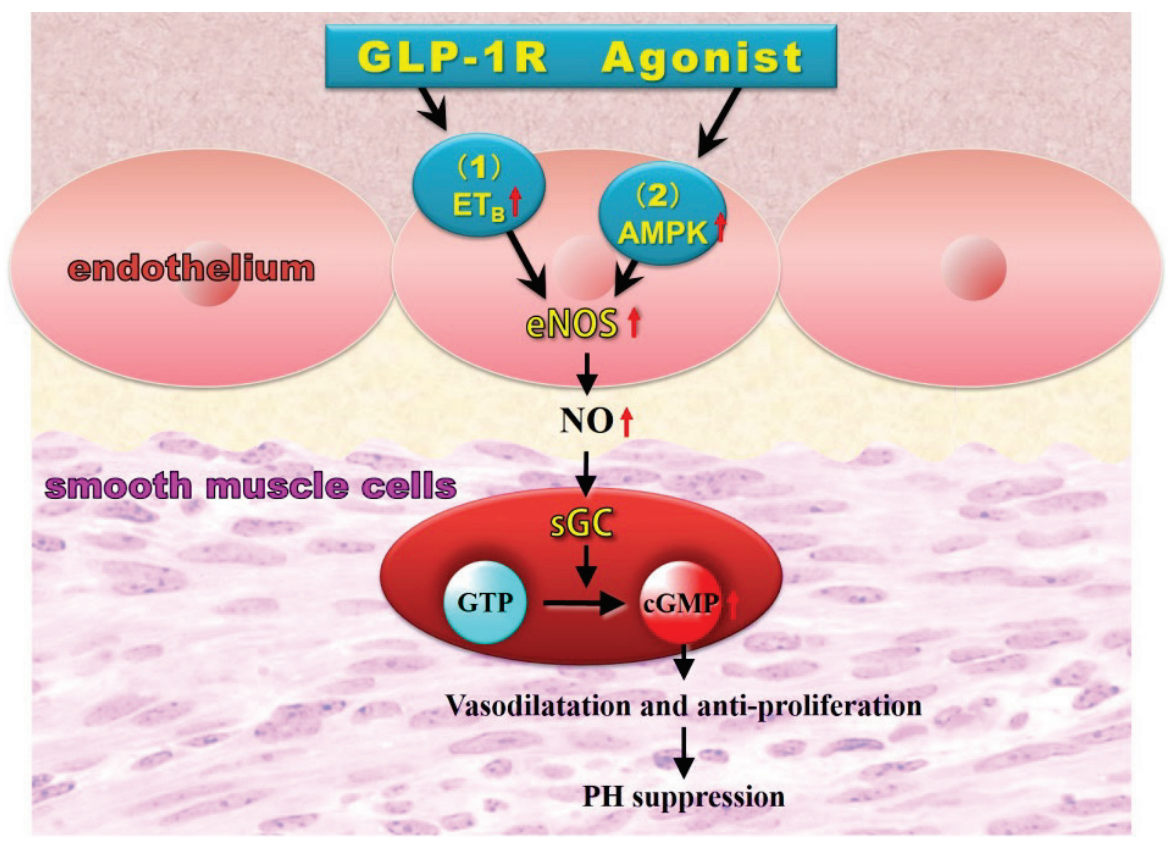

Fig. 5. The scheme of the GLP-1R agonist liraglutide activates eNOS pathway. The inhibition of PH development by liraglutide may be caused by eNOS activation in the endothelial cells of pulmonary artery. eNOS activation by liraglutide was mediated by two pathways in the mouse model of hypoxia-induced PH, namely, $\mathrm{ET}_{\mathrm{B}}$ and AMPK signaling pathways. AMPK, adenosine monophosphate-activated protein kinase; cGMP, cyclic guanosine monophosphate; eNOS, endothelial nitric oxide synthase; $\mathrm{ET}_{\mathrm{B}}$, endothelin receptor type B; GLP-1R, glucagon like peptide-1 receptor; GTP, guanosine triphosphate; NO, nitric oxide; PH, pulmonary hypertension; SGC, soluble guanylate cyclase. 
It has been reported that adenosine monophosphate-activated protein kinase (AMPK) causes activation of eNOS in endothelial cells (Thors et al. 2011, Omura et al. 2016). Therefore, we studied the effects of liraglutide on AMPK pathway in a mouse model of $\mathrm{PH}$. The present study also demonstrated for the first time that the GLP-1R agonist liraglutide augmented the expression of phospho-AMPK protein in the lungs of a mouse model of hypoxia-induced PH. AMPK has been reported to have protective effects on endothelial cells. It was also reported that AMPK was activated by fibrates (Murakami et al. 2006), statins (Sun et al. 2006), and metformin (Hawley et al. 2002), which are associated with antiarteriosclerotic actions. The present findings revealed that the activation of eNOS by liraglutide was partly induced via AMPK pathway in the endothelial cells of pulmonary artery. Therefore, liraglutide exerts its beneficial effects on the development of PH via augmentation of AMPK pathway as well as $\mathrm{ET}_{\mathrm{B}}$ pathway (Fig. 5).

In this present study, blood sugar levels were reduced in mice under chronic hypoxia. Previous reports showed that chronic hypoxia $\left(10 \% \mathrm{O}_{2}\right)$ decreased plasma glucose levels in mice because hypoxia-induced translocation of intracellular GLUT4 to the sarcolemma increased glucose uptake in soleus muscle (Gamboa et al. 2011, Mackenzie et al. 2016). Therefore, we might suggest that lower blood sugar level in hypoxia mice is mediated via increased glucose uptake in skeletal muscles.

In conclusion, this is the first study to demonstrate that the GLP-1R agonist liraglutide effectively improves RVSP and RV hypertrophy in a mouse model of hypoxia-induced $\mathrm{PH}$ by activating eNOS via normalization of impaired $\mathrm{ET}_{\mathrm{B}}$ pathway as well as augmentation of AMPK pathway in the lungs. Taken together, GLP-1R agonists are expected to be promising therapeutic agents for the treatment of $\mathrm{PH}$.

\section{Conflict of Interest}

There is no conflict of interest.

\section{Acknowledgements}

We thank Ms. Naomi Tojo and Ms. Mari Nakagawa for their expert technical assistance. This work was supported by JSPS KAKENHI (Grant Numbers 16H05220, 15K15318, 25293125, and 24590654).

\section{References}

ARAKAWA M, MITA T, AZUMA K, EBATO C, GOTO H, NOMIYAMA T, FUJTTANI Y, HIROSE T, KAWAMORI R, WATADA $\mathrm{H}$ : Inhibition of monocyte adhesion to endothelial cells and attenuation of atherosclerotic lesion by a glucagon-like peptide-1 receptor agonist, exendin-4. Diabetes 59: 1030-1037, 2010.

BAN K, NOYAN-ASHRAF MH, HOEFER J, BOLZ SS, DRUCKER DJ, HUSAIN M: Cardioprotective and vasodilatory actions of glucagon-like peptide 1 receptor are mediated through both glucagon-like peptide 1 receptor-dependent and -independent pathways. Circulation 117: 2340-2350, 2008.

BARST RJ, MCGOON M, TORBICKI A, SITBON O, KROWKA MJ, OLSCHEWSKI H, GAINE S: Diagnosis and differential assessment of pulmonary arterial hypertension. J Am Coll Cardiol 43: 40S-47S, 2004.

BARTON M, SOROKIN A: Endothelin and the glomerulus in chronic kidney disease. Semin Nephrol 35: 156-167, 2016.

BARTON M, YANAGISAWA M: Endothelin: 20 years from discovery to therapy. Can J Physiol Pharmacol 86: 485-498, 2008.

CLOZEL M: Endothelin research and the discovery of macitentan for the treatment of pulmonary arterial hypertension. Am J Physiol Regul Integr Comp Physiol 311: R721-R726, 2016.

DAI Y, MEHTA JL, CHEN M: Glucagon-like peptide-1 receptor agonist liraglutide inhibits endothelin-1 in endothelial cell by repressing nuclear factor-kappa B activation. Cardiovasc Drugs Ther 27: 371-380, 2013.

DAVENPORT AP, HYNDMAN KA, DHAUN N, SOUTHAN C, KOHAN DE, POLLOCK JS, POLLOCK DM, WEBB DJ, MAGUIRE JJ: Endothelin. Pharmacol Rev 68: 357-418, 2016.

DE NUCCI G, THOMAS R, D'ORLEANS-JUSTE P, ANTUNES E, WALDER C, WARNER TD, VANE JR: Pressor effects of circulating endothelin are limited by its removal in the pulmonary circulation and by the release of prostacyclin and endothelium-derived relaxing factor. Proc Natl Acad Sci U S A 85: 9797-9800, 1988.

DRUCKER DJ: The biology of incretin hormones. Cell Metab 3: 153-165, 2006. 
DUPUIS J, GORESKY CA, FOURNIER A: Pulmonary clearance of circulating endothelin-1 in dogs in vivo: exclusive role of $\mathrm{ET}_{\mathrm{B}}$ receptors. J Appl Physiol 81: 1510-1515, 1996.

FRUMKIN LR: The pharmacological treatment of pulmonary arterial hypertension. Pharmacol Rev 64: 583-620, 2012.

FUKURODA T, FUJIKAWA T, OZAKI S, ISHIKAWA K, YANO M, NISHIKIBE M: Clearance of circulating endothelin-1 by ET $_{B}$ receptors in rats. Biochem Biophys Res Commun 199: 1461-1465, 1994.

GAMBOA JL, GARCIA-CAZARIN ML, ANDRADE FH: Chronic hypoxia increases insulin-stimulated glucose uptake in mouse soleus muscle. Am J Physiol Regul Integr Comp Physiol 300: R85-R91, 2011.

GAO J, ZHAO L, SHAHZAD M, ZHANG D, LIU G, HOU B, LI J: Expression of endothelin-1 and its receptors in the lungs of broiler chickens exposed to high-altitude hypoxia. Avian Pathol 42: 416-419, 2013.

GARG UC, HASSID A: Nitric oxide-generating vasodilators and 8-bromo-cyclic guanosine monophosphate inhibit mitogenesis and proliferation of cultured rat vascular smooth muscle cells. J Clin Invest 83: 1774-1777, 1989.

GASPARI T, LIU H, WELUNGODA I, HU Y, WIDDOP RE, KNUDSEN LB, SIMPSON RW, DEAR AE: A GLP-1 receptor agonist liraglutide inhibits endothelial cell dysfunction and vascular adhesion molecule expression in an ApoE $^{-/-}$mouse model. Diab Vasc Dis Res 8: 117-124, 2013.

GIAID A, SALEH D: Reduced expression of endothelial nitric oxide synthase in the lungs of patients with pulmonary hypertension. N Engl J Med 333: 214-221, 1995.

GOHAR EY, GIACHINI FR, POLLOCK DM, TOSTES RC: Role of the endothelin system in sexual dimorphism in cardiovascular and renal diseases. Life Sci 159: 20-29, 2016.

GOTO H, NOMIYAMA T, MITA T, YASUNARI E, AZUMA K, KOMIYA K, ARAKAWA M, JIN WL, KANAZAWA A, KAWAMORI R, FUJITANI Y, HIROSE T, WATADA H: Exendin-4, a glucagon-like peptide-1 receptor agonist, reduces intimal thickening after vascular injury. Biochem Biophys Res Commun 405: 79-84, 2011.

HALL SM, DAVIE N, KLEIN N, HAWORTH SG: Endothelin receptor expression in idiopathic pulmonary arterial hypertension: effect of bosentan and epoprostenol treatment. Eur Respir J 38: 851-860, 2011.

HAWLEY SA, GADALLA AE, OLSEN GS, HARDIE DG: The antidiabetic drug metformin activates the AMP-activated protein kinase cascade via an adenine nucleotide-independent mechanism. Diabetes 51: 2420-2425, 2002.

HOSODA K, NAKAO K, HIROSHI-ARAI, SUGA S, OGAWA Y, MUKOYAMA M, SHIRAKAMI G, SAITO Y, NAKANISHI S, IMURA H: Cloning and expression of human endothelin-1 receptor cDNA. FEBS Lett 287: 23-26, 1991.

IRWIN DM: Molecular evolution of proglucagon. Regul Pept 98: 1-12, 2001.

KEDZIERSKI RM, YANAGISAWA M: Endothelin system: the double-edged sword in health and disease. Annu Rev Pharmacol Toxicol 41: 851-876, 2001.

LIU H, DEAR AE, KNUDSEN LB, SIMPSON RW: A long-acting glucagon-like peptide-1 analogue attenuates induction of plasminogen activator inhibitor type-1 and vascular adhesion molecules. $J$ Endocrinol 201: 59-66, 2009.

MACKENZIE RW, WATT P: A molecular and whole body insight of the mechanisms surrounding glucose disposal and insulin resistance with hypoxic treatment in skeletal muscle. J Diabetes Res 2016: 6934937, 2016.

MIYAUCHI T, GOTO K: Cardiovasucular peptides: Endothelins. In: Handbook of Biologically Active Peptides Second Edition. KASTIN AJ (ed.), Academic Press, Elsevier Inc., San Diego, 2013, pp 1402-1407.

MIYAUCHI T, YORIKANE R, SAKAI S, SAKURAI T, OKADA M, NISHIKIBE M, YANO M, YAMAGUCHI I, SUGISHITA Y, GOTO K: Contribution of endogenous endothelin-1 to the progression of cardiopulmonary alterations in rats with monocrotaline-induced pulmonary hypertension. Circ Res 73: 887-897, 1993.

MURAKAMI H, MURAKAMI R, KAMBE F, CAO X, TAKAHASHI R, ASAI T, HIRAI T, NUMAGUCHI Y, OKUMURA K, SEO H, MUROHARA T: Fenofibrate activates AMPK and increases eNOS phosphorylation in HUVEC. Biochem Biophys Res Commun 341: 973-978, 2006.

NOYAN-ASHRAF MH, SHIKATANI EA, SCHUIKI I, MUKOVOZOV I, WU J, LI RK, VOLCHUK A, ROBINSON LA, BILLIA F, DRUCKER DJ, HUSAIN M: A glucagon-like peptide-1 analog reverses the molecular pathology and cardiac dysfunction of a mouse model of obesity. Circulation 127: 74-85, 2013. 
OGAWA Y, NAKAO K, ARAI H, NAKAGAWA O, HOSODA K, SUGA S, NAKANISHI S, IMURA H: Molecular cloning of a non-isopeptide-selective human endothelin receptor. Biochem Biophys Res Commun 178: 248-255, 1991.

OMURA J, SATOH K, KIKUCHI N, SATOH T, KUROSAWA R, NOGI M, OTSUKI T, KOZU K, NUMANO K, SUZUKI K, SUNAMURA S, TATEBE S, AOKI T, SUGIMURA K, MIYATA S, HOSHIKAWA Y, OKADA Y, SHIMOKAWA H: Protective roles of endothelial AMP-activated protein kinase against hypoxia-induced pulmonary hypertension in mice. Circ Res 119: 197-209, 2016.

RODRÍGUEZ-PASCUAL F, BUSNADIEGO O, LAGARES D, LAMAS S: Role of endothelin in the cardiovascular system. Pharmacol Res 63: 463-472, 2011.

RUBIN LJ: Endothelin receptor antagonists for the treatment of pulmonary artery hypertension. Life Sci 91: 517-521, 2012.

SAKAI S, MARUYAMA H, TAJIRI K, HONDA J, HOMMA S, AONUMA K, MIYAUCHI T: Antagonists to endothelin receptor type B promote apoptosis in human pulmonary arterial smooth muscle cells. Life Sci 159: 116-120, 2016.

SEIMETZ M, PARAJULI N, PICHL A, VEIT F, KWAPISZEWSKA G, WEISEL FC, MILGER K, EGEMNAZAROV B, TUROWSKA A, FUCHS B, NIKAM S, ROTH M, SYDYKOV A, MEDEBACH T, KLEPETKO W, JAKSCH P, DUMITRASCU R, GARN H, VOSWINCKEL R, KOSTIN S, SEEGER W, SCHERMULY RT, GRIMMINGER F, GHOFRANI HA, WEISSMANN N: Inducible NOS inhibition reverses tobacco-smokeinduced emphysema and pulmonary hypertension in mice. Cell 147: 293-305, 2011.

SHIRAKAWA J, TANAMI R, TOGASHI Y, TAJIMA K, ORIME K, KUBOTA N, KADOWAKI T, GOSHIMA Y, TERAUCHI Y: Effects of liraglutide on $\beta$-cell-specific glucokinase-deficient neonatal mice. Endocrinology 153: 3066-3075, 2012.

SUN W, LEE TS, ZHU M, GU C, WANG Y, ZHU Y, SHYY JY: Statins activate AMP-activated protein kinase in vitro and in vivo. Circulation 114: 2655-2662, 2006.

THORIN E, WEBB DJ: Endothelium-derived endothelin-1. Pflugers Arch 459: 951-958, 2010.

THORS B, HALLDÓRSSON H, THORGEIRSSON G: eNOS activation mediated by AMPK after stimulation of endothelial cells with histamine or thrombin is dependent on LKB1. Biochim Biophys Acta 1813: 322-331, 2011.

WANG JW, LI AY, GUO QH, GUO YJ, WEISS JW, JI ES: Endothelin-1 and ET receptors impair left ventricular function by mediated coronary arteries dysfunction in chronic intermittent hypoxia rats. Physiol Rep 5: e13050, 2017.

WANG Z, LI AY, GUO QH, ZHANG JP, AN Q, GUO YJ, CHU L, WEISS JW, JI ES: Effects of cyclic intermittent hypoxia on ET-1 responsiveness and endothelial dysfunction of pulmonary arteries in rats. PLoS One 8: e58078, 2013.

WARNER TD, MITCHELL JA, DE NUCCI G, VANE JR: Endothelin-1 and endothelin-3 release EDRF from isolated perfused arterial vessels of the rat and rabbit. J Cardiovasc Pharmacol 13: S85-S88, 1989.

XU D, MURAKOSHI N, IGARASHI M, HIRAYAMA A, ITO Y, SEO Y, TADA H, AONUMA K: PPAR- $\gamma$ activator pioglitazone prevents age-related atrial fibrillation susceptibility by improving antioxidant capacity and reducing apoptosis in a rat model. J Cardiovasc Electrophysiol 23: 209-217, 2012.

YANAGISAWA M, KURIHARA H, KIMURA S, TOMOBE Y, KOBAYASHI M, MITSUI Y, YAZAKI Y, GOTO K, MASAKI T: A novel potent vasoconstrictor peptide produced by vascular endothelial cells. Nature 332: 411-415, 1988.

ZHANG W, WANG W, LIU J, LI J, WANG J, ZHANG Y, ZHANG Z, LIU Y, JIN Y, LI J, CAO J, WANG C, NING W, WANG J: Follistatin-like 1 protects against hypoxia-induced pulmonary hypertension in mice. Sci Rep 7: 45820, 2017. 